\title{
Rypsi soijaa parempi lypsylehmien valkuaistäydennys myös apilapitoista säilörehua syötettäessä
}

\author{
Marketta Rinne $^{1)}$, Kaisa Kuoppala ${ }^{1)}$, Seppo Ahvenjärvi ${ }^{1)}$ ja Aila Vanhatalo ${ }^{2)}$ \\ ${ }^{1)}$ MTT (Maa- ja elintarviketalouden tutkimuskeskus), Kotieläintuotannon tutkimus, 31600 Jokioinen, \\ etunimi.sukunimi@mtt.fi \\ ${ }^{2)}$ Kotieläintieteen laitos, MMTDK, 00014 Helsingin yliopisto, etunimi.sukunimi@helsinki.fi
}

\section{Tiivistelmä}

Suurin osa lypsylehmien valkuaistäydennystä selvittävistä tutkimuksista on suoritettu nurmiheinäkasveista tehtyyn säilörehuun perustuvia ruokintoja käyttäen. Puna-apilapitoisen säilörehun käyttäminen on kuitenkin tyypillistä luomutuotannossa. Puna-apilan typpiomavaraisuus, myöhäisempi kehitysrytmi ja lehmien kyky syödä sitä runsaasti ovat ominaisuuksia, jotka puoltavat sen käyttöä myös tavanomaisessa viljelyssä. Tässä tutkimuksessa selvitettiin valkuaislähteen (rypsi- tai soijapuriste) ja valkuaisrehun määrän vaikutusta lypsylehmien ravintoaineiden saantiin ja maidontuotantoon fysiologisessa kokeessa, kun säilörehusta puolet oli puna-apilaa.

Valkuaisrehuannoksen suurentaminen lisäsi lehmien kuiva-aineen, rehuyksiköiden ja ohutsuolesta imeytyvän valkuaisen saantia sekä maidontuotantoa (taulukko). Lypsylehmien maidontuotantovasteet olivat samaa luokkaa kuin aikaisemmissa kotimaisissa kokeissa, joissa oli käytetty nurmiheinäkasveista tehtyä säilörehua. Rypsipuriste osoittautui myös tässä kokeessa soijapuristetta paremmaksi valkuaistäydennykseksi, kun maitotuotosvaste laskettiin valkuaisrehukiloja tai rehun raakavalkuaista kohti. Kokeessa käytettiin kohtuullisen runsaita valkuaisrehuannoksia. Maitotuotosvasteet olivat suurempia ensimmäisen kuin toisen lisäysmäärän jälkeen erityisesti rypsipuristetta käytettäessä, vaikka käyräviivainen vaikutus ei tilastollisessa analyysissä tullut merkitseväksi. Typen hyväksikäyttö maidontuotannossa huononi valkuaisrehuannosta lisättäessä ja oli soijapuristetta käytettäessä huonompi kuin rypsipuristeella. Ravinteiden hyväksikäyttö maidontuotannossa ei kuitenkaan vaikuta suoraan karjatilan taloudelliseen tulokseen, joten valkuaisrehun taloudellinen käyttömäärä riippuu pääasiassa maidon ja rehujen keskinäisistä hinnoista.

Asiasanat: Nurmipalkokasvi, puna-apila, rypsipuriste, soijapuriste, valkuaisrehu, aminohappo, luomu, maidontuotanto

\begin{tabular}{|c|c|c|c|c|c|c|c|c|c|c|}
\hline \multirow[b]{2}{*}{ Valkuaismäärä } & \multirow{2}{*}{$\begin{array}{c}\text { Kontrolli } \\
0\end{array}$} & \multicolumn{2}{|c|}{ Rypsipuriste } & \multicolumn{2}{|c|}{ Soijapuriste } & \multirow{2}{*}{ SEM } & \multicolumn{4}{|c|}{ Tilastollinen merkitsevyys ${ }^{1)}$} \\
\hline & & 1 & 2 & 1 & 2 & & RvsS & Lin & Quad & $1 * \mathrm{~L}$ \\
\hline \multicolumn{11}{|c|}{ Rehujen syönti ja ravintoaineiden saanti päivässä } \\
\hline Kuiva-aine (KA; kg) & 19.6 & 21.4 & 21.7 & 20.3 & 20.7 & 0.45 & * & * & & \\
\hline Säilörehu (kg KA) & 12.7 & 13.3 & 13.6 & 12.3 & 13.0 & 0.38 & o & & & \\
\hline Valk.rehu (kg KA) & 0 & 1.78 & 3.34 & 1.34 & 2.51 & --- & & & & \\
\hline Raakavalk. (kg) & 2.89 & 3.62 & 4.15 & 3.47 & 4.07 & 0.064 & & $* * *$ & & \\
\hline Rehuyksiköt (RY) & 18.9 & 20.7 & 20.9 & 19.9 & 20.4 & 0.47 & & * & & \\
\hline OIV (g) & 1766 & 2062 & 2210 & 1921 & 2045 & 42.5 & ** & $* * *$ & & * \\
\hline PVT (g) & -35 & 248 & 575 & 322 & 740 & 19.5 & $* * *$ & $* * *$ & & $* * *$ \\
\hline \multicolumn{11}{|l|}{ Maidontuotanto } \\
\hline Maito $(\mathrm{kg} / \mathrm{pv})$ & 32.7 & 35.3 & 35.8 & 33.7 & 34.1 & 0.91 & & o & & * \\
\hline Rasva $(\mathrm{g} / \mathrm{kg})$ & 37.6 & 37.7 & 38.2 & 38.0 & 37.0 & 1.59 & & & & \\
\hline Valkuainen $(\mathrm{g} / \mathrm{kg})$ & 29.8 & 30.9 & 30.7 & 29.5 & 30.4 & 0.48 & & & & \\
\hline Urea $(\mathrm{mg} / 100 \mathrm{ml})$ & 18.1 & 25.8 & 29.9 & 26.1 & 34.0 & 1.91 & & *** & & \\
\hline \multicolumn{11}{|c|}{ Koko rehuannoksen sulavuus lehmillä kokonaiskeruulla määritettynä $(\mathrm{g} / \mathrm{kg})$} \\
\hline Orgaaninen aine & 710 & 708 & 712 & 727 & 733 & 4.6 & $* *$ & o & & $*$ \\
\hline Raakavalkuainen & 618 & 642 & 672 & 663 & 704 & 7.6 & ** & $* * *$ & & * \\
\hline \multicolumn{11}{|c|}{ Plasman aminohappojen pitoisuus $(\mu \mathrm{mol} / \mathrm{l})$} \\
\hline Haaraketjuiset & 598 & 723 & 801 & 709 & 778 & 69.9 & & o & & \\
\hline Välttämättömät & 974 & 1135 & 1247 & 1157 & 1163 & 93.5 & & o & & \\
\hline Ei-välttämättömät & 1112 & 1107 & 1139 & 1165 & 974 & 34.4 & & & & $* *$ \\
\hline Yhteensä & 2087 & 2242 & 2385 & 2321 & 2137 & 124.6 & & & & \\
\hline
\end{tabular}

${ }^{1}$ Kontrastit: RvsS = rypsi- vs. soijapuriste, Lin $=$ valkuaisrehun suoraviivainen vaikutus, Quad $=$ valkuaisrehun käyräviivainen vaikutus, $1 * \mathrm{~L}=$ Valkuaislähteen ja valkuaisrehun määrän lin. vaikutuksen yhdysvaikutus. 


\section{Johdanto}

Suurin osa lypsylehmien valkuaistäydennystä selvittävistä tutkimuksista on suoritettu nurmiheinäkasveista tehtyyn säilörehuun perustuvia ruokintoja käyttäen. Puna-apilapitoisen säilörehun käyttäminen on kuitenkin tyypillistä luomutuotannossa. Puna-apilan typpiomavaraisuus, myöhäisempi kehitysrytmi ja lehmien kyky syödä sitä runsaasti ovat ominaisuuksia, jotka puoltavat sen käyttöä myös tavanomaisessa viljelyssä. Tässä tutkimuksessa selvitettiin valkuaislähteen (rypsi- tai soijapuriste) ja valkuaisrehun määrän vaikutusta lypsylehmien ravintoaineiden saantiin ja maidontuotantoon fysiologisessa kokeessa, kun perusrehuna käytetystä säilörehusta puolet oli puna-apilaa. Aikaisemmissa kotimaisissa tutkimuksissa rypsirehujen maidontuotantovaikutus on ollut soijapohjaisia valkuaisrehuja parempi, kun perusrehuna on käytetty nurmiheinäkasveista tehtyä säilörehua (Vanhatalo ym. 2004). Tässä kokeessa käytettiin varsin suuria valkuaisrehuannoksia, koska monissa aikaisemmissa tutkimuksissa maidontuotanto on lisääntynyt suoraviivaisesti melko suuriakin valkuaisrehumääriä käytettäessä (Rinne ym. 1999).

Tutkimus kuului MMM:n osittain rahoittamaan luomututkimusohjelmaan, joten kokeessa käytettiin luomutuotannossa sallittuja puristusmenetelmällä valmistettuja valkuaisrehuja. Säilörehu sisälsi puolet puna-apilaa eli se vastasi luomutuotannossa tyypillisesti käytettävää karkearehua. Myös väkirehun osuus kuiva-aineen kokonaissyönnistä pidettiin luomusäännösten mukaisena.

\section{Aineisto ja menetelmät}

Kokeessa selvitettiin valkuaislähteen (rypsi- vs. soijapuriste) ja valkuaisrehun määrän vaikutusta lehmien ravintoaineiden saantiin, kun säilörehu sisälsi puolet puna-apilaa. Koerehuina käytettiin Mildola Oy:n valmistamia rypsipuristetta (Öpex $\left.{ }^{\circledR}\right)$ ja soijapuristetta. Valkuaisrehuja annosteltiin lehmille siten, että ne saivat molemmista yhtä paljon raakavalkuaista (RV) päivässä tasoilla 1 ja 2. Koska rypsipuristeen valkuaispitoisuus oli pienempi kuin soijapuristeen, sen päiväannokset olivat suurempia. Päivittäiset rypsipuristeannokset olivat 2.0 ja $4.0 \mathrm{~kg}$ ja soijapuristeannokset 1.4 ja $2.9 \mathrm{~kg}$. Lisäksi mukana oli kontrolliruokinta, johon ei perusväkirehuna käytetyn ohran ja kauran rakeistetun seoksen lisäksi lisätty lainkaan valkuaisrehua. Koeruokintoja oli siis yhteensä viisi. Väkirehun kokonaismäärä oli kaikissa koeruokinnoissa $9 \mathrm{~kg}$. Perusrehujen lisäksi lehmät saivat hivenainetäydennyksen ja suolaa $(\mathrm{NaCl}) 100$ g/pv. Kivennäistäydennystä lehmille ei annettu lainkaan, koska kalsiumin, fosforin ja magnesiumin saanti rehuannoksesta kattoi lähes täysin eläinten tarpeen.

Koe järjestettiin epätäydellisen Latinalaisen neliön mukaan siten, että 21 päivän pituisia koejaksoja oli neljä. Kaikki lehmät söivät kokeen aikana samaa säilörehua. Säilörehu koostui puhtaasta puna-apilakasvustosta tehdystä säilörehusta ja timoteinurminatakasvustosta tehdystä säilörehusta, jotka sekoitettiin ennen ruokintaa seosrehuvaunulla siten, että kuiva-aineeksi laskettuna molempia rehuja oli yhtä paljon (1:1). Molemmat säilörehut oli korjattu MTT:n Jokioisten kartanoiden pelloilta nurmen ensimmäisestä sadosta. Puna-apilasäilörehu (lajike Jokioinen, toinen satovuosi) oli korjattu 22.7.2004 aumaan ja timoteinurminatasäilörehu (timoteilajike Tammisto II ja nurminatalajike Antti, toinen satovuosi) 15.6.2004 laakasiiloon tarkkuussilppurilla. Säilöntäaineena käytettiin AIV2 Plussaa apilalle 6.5 $1 / \mathrm{t}$ ja timoteinurminadalle 5.0 1/t. Puna-apilanurmea ei lannoitettu lainkaan ja se vastasi 2 . vuoden luomuun siirtymävaiheessa olevaa kasvustoa, mutta heinäkasvinurmi oli lannoitettu keväällä väkilannoitteella (370 kg Suomen salpietaria/ha eli $96 \mathrm{~kg} \mathrm{~N} / \mathrm{ha}$ ).

Koe suoritettiin Jokioisilla MTT Eläinravitsemuksen Koe-eläintallilla 22.10.2004-14.1.2005. Kokeessa oli viisi pysyvin pötsifistelein eli -avantein varustettua ja vähintään kaksi kertaa poikinutta ayrshirelehmää. Kokeen alkaessa lehmien poikimisesta oli kulunut 51 päivää (keskihajonta 12.6 päivää) ja niiden maitotuotos oli $39.2 \mathrm{~kg}$ (keskihajonta $4.20 \mathrm{~kg}$ ). Lehmien paino keskimäärin kokeen aikana oli $654 \mathrm{~kg}$ (keskihajonta $62.9 \mathrm{~kg}$ ). Jokaisen jakson ensimmäisten 14 päivän ajan lehmät saivat syödä säilörehua vapaasti. Viimeisen viikon ajaksi lehmien säilörehuannos rajoitettiin 95 prosenttiin vapaasta syönnistä, jotta päivittäiset vaihtelut syödyn rehun määrässä aiheuttaisivat mahdollisimman vähän vaihtelua mittaustuloksiin.

Pötsikäymistä selvitettiin jakson 14. päivänä ottamalla näytteitä pötsinesteestä ennen aamuruokintaa klo 6.00 ja sen jälkeen 6 kertaa 1.5 tunnin välein, jolloin koko ruokintaväli tuli katettua. Koeruokintojen kokonaissulavuus määritettiin sonnan kokonaiskeruun avulla. Kaikki sonta kerättiin talteen jakson viimeisten neljän vuorokauden ajan. Sonnan määrä punnittiin ja siitä otettiin edustavat näytteet analyysejä varten. Ravintoaineiden virtaus ohutsuoleen määritettiin satakertanäytteenottotekniikalla käyttäen kolmen merkkiaineen menetelmää. Merkkiaineina olivat Cr-EDTA (nesteosa), Yb 
(pienet partikkelit) ja INDF (suuret partikkelit). Ruokasulanäytteitä otettiin satakerrasta näytteenottolaitteella neljänä eri päivänä kolmasti päivässä siten, että koko ruokintaväli tuli tunneittain katettua. Jokaisen jakson viimeisenä päivänä lehmien häntäsuonesta otettiin verinäytteet ennen aamuruokintaa klo 6 sekä klo 9 ja 12. Yhdistetyistä plasmanäytteistä määritettiin $\mathrm{mm}$. aminohappojen pitoisuudet.

Koerehuista otettiin keruukausien aikana päivittäin edustavat näytteet. Säilörehunäytteet analysoitiin jaksoittain, mutta viljaseoksen ja valkuaisrehujen jaksoittaiset näytteet yhdistettiin analyysejä varten. Rehu- ja muut näytteet analysoitiin MTT Eläinravitsemuksen vastuualueen laboratoriossa standardimenetelmin. Tulokset analysoitiin tilastollisesti SAS GLM -proseduurilla mallilla, jossa olivat mukana jakson, lehmän ja ruokinnan vaikutukset. Ruokinnan vaikutus jaettiin edelleen kontrastein valkuaislähteiden vertailuun, valkuaismäärän suoraviivaiseen ja toisen asteen käyräviivaiseen vaikutukseen sekä valkuaislähteen ja valkuaismäärän yhdysvaikutuksiin.

Taulukko 1. Rehujen koostumus, rehuarvot ja säilörehujen käymislaatu.

\begin{tabular}{|c|c|c|c|c|c|c|}
\hline & $\begin{array}{c}\text { Puna-apila- } \\
\text { säilörehu }\end{array}$ & $\begin{array}{l}\text { Timotei- } \\
\text { nurminata- } \\
\text { säilörehu }\end{array}$ & $\begin{array}{c}\text { Säilö- } \\
\text { rehuseos }\end{array}$ & $\begin{array}{l}\text { Ohra- } \\
\text { kaura }\end{array}$ & $\begin{array}{l}\text { Rypsi- } \\
\text { puriste }\end{array}$ & $\begin{array}{l}\text { Soija- } \\
\text { puriste }\end{array}$ \\
\hline Kuiva-aine (KA; g/kg) & 198 & 262 & 221 & 879 & 909 & 912 \\
\hline \multicolumn{7}{|l|}{ Kuiva-aineessa (g/kg KA) } \\
\hline Tuhka & 78 & 81 & 80 & 29 & 68 & 61 \\
\hline Raakavalkuainen & 185 & 138 & 157 & 128 & 371 & 480 \\
\hline Raakarasva & & & & 43 & 94 & 76 \\
\hline Solunseinäkuitu (NDF) & 492 & 513 & 498 & 363 & 371 & 288 \\
\hline Sulamaton kuitu (INDF) & & & 101 & 73 & 133 & 1 \\
\hline \multicolumn{7}{|l|}{ Kivennäis- ja hivenainepitoisuus } \\
\hline Kalsium & & & 6.97 & 1.00 & 8.00 & 2.88 \\
\hline Magnesium & & & 2.13 & 1.43 & 4.66 & 3.12 \\
\hline Fosfori & & & 2.86 & 4.16 & 10.54 & 6.10 \\
\hline Rikki & & & 2.12 & 1.63 & 6.39 & 3.91 \\
\hline Kalium & & & 26.8 & 5.3 & 12.7 & 23.3 \\
\hline Natrium (mg/kg KA) & & & 35 & 109 & 80 & 40 \\
\hline Rauta (mg/kg KA) & & & 845 & 86 & 135 & 206 \\
\hline Kupari (mg/kg KA) & & & 9 & 7 & 6 & 14 \\
\hline Sinkki (mg/kg KA) & & & 30 & 38 & 61 & 50 \\
\hline Mangaani (mg/kg KA) & & & 37 & 32 & 69 & 35 \\
\hline \multicolumn{7}{|l|}{ Rehuarvot ja sulavuus } \\
\hline $\mathrm{RY} / \mathrm{kg} \mathrm{KA}$ & 0.84 & 0.98 & 0.91 & 1.06 & 1.04 & 1.20 \\
\hline $\operatorname{ME}(\mathrm{MJ} / \mathrm{kg} \mathrm{KA})$ & 9.9 & 11.5 & 10.7 & 12.4 & 12.2 & 14.0 \\
\hline OIV & 84.6 & 86.7 & 85.7 & 97.8 & 160.7 & 157.1 \\
\hline PVT & 39.0 & -9.8 & 14.6 & -31.6 & 126.4 & 236.2 \\
\hline Sellulaasiliukoisuus (g/kg) & 719 & 814 & 768 & & & \\
\hline In vitro $\mathrm{OAS}^{1)}(\mathrm{g} / \mathrm{kg})$ & 669 & 783 & $726^{2)}$ & & & \\
\hline D-arvo & 617 & 719 & $668^{2)}$ & & & \\
\hline Syönti-indeksi & 91.7 & 106.1 & $98.9^{2)}$ & & & \\
\hline \multicolumn{7}{|l|}{ Säilörehujen säilönnällinen laatu } \\
\hline $\mathrm{pH}$ & 3.79 & 4.20 & 3.95 & & & \\
\hline Etikkahappo & 11.5 & 15.2 & 14.4 & & & \\
\hline Propionihappo & 0.05 & 0.07 & 0.07 & & & \\
\hline Isovoihappo & 0 & 0 & 0 & & & \\
\hline Voihappo & 0.25 & 0.41 & 0.27 & & & \\
\hline Isovaleriaanahappo & 0.12 & 0.15 & 0.11 & & & \\
\hline Valeriaanahappo & 0.01 & 0.01 & 0.01 & & & \\
\hline Kapronihappo & 0.02 & 0.01 & 0 & & & \\
\hline Maitohappo & 15.9 & 24.9 & 29.3 & & & \\
\hline Sokerit & 94 & 152 & 108 & & & \\
\hline Ammonium-typpi (g/kg N) & 47.7 & 54.1 & 52.9 & & & \\
\hline Liukoinen typpi (g/kg N) & 297 & 642 & 455 & & & \\
\hline Etanoli & 3.0 & 4.7 & 2.1 & & & \\
\hline
\end{tabular}




\section{Tulokset ja tulosten tarkastelu}

Kokeessa syötetty säilörehuseos oli säilönnälliseltä laadultaan ja rehuarvoiltaan hyvää (Taulukko 1). Seos vastasi hyvin alkuperäisten rehujen koostumusten keskiarvoa. Alkuperäisten rehujen korjuuajassa oli noin 5 viikon ero, vaikka molemmat rehut oli tehty nurmen ensimmäisestä sadosta. Timoteinurminadan D-arvo oli korkea ja RV-pitoisuus matalahko, kun taas apilasäilörehun D-arvo oli matala ja RV-pitoisuus korkeahko. Rypsipuriste sisälsi vähemmän RV:ta ja hieman enemmän raakarasvaa kuin soijapuriste. Koska rypsipuristeen valkuaisen hajoavuus on pienempi kuin soijapuristeen (MTT 2004), molempien valkuaisrehujen OIV-pitoisuudet olivat samaa luokkaa. Rehujen aminohappokoostumus on esitetty taulukossa 2. Aminotypen osuus rehujen kokonaistypestä oli säilörehuseoksessa 0.84 , ohrakaurassa 1.02, rypsipuristeessa 0.93 ja soijapuristeessa 1.02 .

Vaikka kokeessa käytetty väkirehumäärä oli kohtuullinen, väkirehun syönnissä kokeen aikana oli vaihtelua, joka ei kuitenkaan näyttänyt liittyvän tiettyyn ruokintaan. Valkuaisrehut lisäsivät lehmien kuiva-aineen syöntiä sekä RV:n, ME:n ja OIV:n saantia ja vaikutus oli rypsipuristetta syötettäessä suurempi kuin soijalla (Taulukko 3). Valkuaislisä paransi myös dieetin orgaanisen aineen, RV:n ja kuidun sulavuutta ja soijapuristetta sisältävien ruokintojen sulavuudet olivat korkeampia kuin rypsiruokintojen. Vaikutukset rehujen syöntiin ja sulavuuteen olivat yhdenmukaisia aikaisempien kokeiden kanssa (mm. Rinne ym. 1999, Vanhatalo ym. 2004). Lucasin yhtälöllä laskettu rypsipuristeen todellinen sulavuus oli 848 ja soijapuristeen $955 \mathrm{~g} / \mathrm{kg}$. Rypsivalkuaisen sulavuus on tyypillisesti ollut pienempi kuin soijan, mutta tässä kokeessa ero oli pienempi kuin Vanhatalon ym. (2004) kokeessa, jossa rypsipuristeen lisävalkuaisen todellinen sulavuus oli 810 ja soijarouheen $1000 \mathrm{~g} / \mathrm{kg}$.

Koeruokinnat eivät vaikuttaneet pötsikäymiseen merkitsevästi pötsin ammoniakkipitoisuutta lukuun ottamatta, joka suureni valkuaislisän myötä (tuloksia ei esitetty). Kokonaistypen virtaus satakertaan lisääntyi lineaarisesti valkuaisrehuja lisättäessä (Taulukko 3), mutta ei-ammoniakki-typen, mikrobitypen ja aminohappojen virtauksen tulokset eivät vielä ole käytettävissä.

Valkuaisrehuannoksen suurentaminen pienensi plasman vapaiden rasvahappojen (NEFA) ja suurensi plasman urean pitoisuutta (Taulukko 4). Histidiini on aikaisemmissa tutkimuksissa todettu ensimmäiseksi maidontuotantoa rajoittavaksi aminohapoksi tyypillisillä suomalaisilla heinäkasvisäilörehuihin ja rehuviljaan perustuvilla ruokinnoilla (Vanhatalo ym. 1999). Tässä kokeessa kontrolliruokinnalla plasman histidiinipitoisuus oli $34.9 \mu \mathrm{mol} / 1$, mikä on jonkin verran korkeampi kuin aikaisemmissa kotimaisissa heinäkasvisäilörehukokeissa keskimäärin $(24 \mu \mathrm{mol} / 1, \mathrm{n}=13$; ks. Vanhatalo ym. 2002). Aminohappojen saanti perusruokinnasta on kuitenkin pelkästään nurmiheinäkasvisäilörehuihin perustuvissakin ruokinnoissa ollut varsin vaihtelevaa (vaihteluväli 12-42 $\mu \mathrm{mol} / \mathrm{l}$ ).

Valkuaisrehuannoksen suurentaminen lisäsi plasman histidiinin, leusiinin, fenyylialaniinin, valiinin ja proliinin pitoisuuksia, mutta glutamaatin ja glysiinin pitoisuudet pienenivät. Pienentyneet NEFA- ja glysiinipitoisuudet viittaavat pienentyneeseen kudosvarastojen mobilisaatioon valkuaisrehuannosta lisättäessä. Yhteenlaskettujen haaraketjuisten ja välttämättömien aminohappojen pitoisuudet plasmassa näyttivät lisääntyvän valkuaisrehuannosta lisättäessä. Valkuaisrehujen väliset erot plasman aminohappopitoisuuksissa olivat vähäisiä hieman suurempaa rypsiruokintojen metioniini- ja treoniinipitoisuutta lukuun ottamatta. Ylipäätään plasman metioniinipitoisuus oli tässä kokeessa matalahko ja korkeimmalla soijapuristetasolla erityisen pieni.

Valkuaisrehujen lisääntynyt saanti suurensi lehmien maitotuotosta (Taulukko 5). Vaikutukset maidon koostumukseen olivat vähäisiä maidon ureapitoisuutta lukuun ottamatta, joka lisääntyi valkuaisrehumäärän myötä. Rypsipuristetta saaneiden lehmien maidon valkuaispitoisuus oli hieman korkeampi kuin soijapuristetta saaneiden $(\mathrm{P}=0.1)$.

Maidontuotantovasteet olivat rypsipuristetta syötettäessä suurempia kuin soijapuristeruokinnoilla. Vasteet olivat suurempia ensimmäisen kuin toisen lisäysmäärän jälkeen erityisesti rypsipuristetta käytettäessä, vaikka toisen asteen vaikutus ei tilastollisessa analyysissä tullut merkitseväksi. Energiakorjatun maidon tuotos lisääntyi valkuaisrehun kuiva-ainekiloa kohti rypsipuristeen tasoilla 1 ja 2 keskimäärin $1.63 \mathrm{ja} 1.02 \mathrm{~kg} / \mathrm{pv}$ ja soijapuristeruokinnoilla $0.82 \mathrm{ja} 0.52 \mathrm{~kg} / \mathrm{pv}$. Samat vasteet maitovalkuaisen päivittäisessä tuotannossa olivat rypsitasoilla 1 ja 2 keskimäärin 67 ja $37 \mathrm{~g}$ ja soijatasoilla $1 \mathrm{ja}$ 2 puolestaan 17 ja $26 \mathrm{~g}$.

Kokkosen (2005) kirjallisuusyhteenvedon mukaan dieetin raakavalkuaispitoisuuden nostaminen rypsirehuilla lisäsi grammaa kohti laskettuna maitotuotosta kaksi kertaa enemmän kuin soijapohjaisia rehuja käytettäessä (0.091 vs. $0.046 \mathrm{~kg} / 1 \mathrm{~g}$ lisäys dieetin RV-pitoisuudessa). Tässä kokeessa rypsipuriste oli suhteellisesti vielä parempi, sillä maitotuotosvasteet dieetin RV-pitoisuuden lisäänty- 
Taulukko 2. Aminohappojen pitoisuus (g/100 g raakavalkuaista) rehuissa.

\begin{tabular}{|c|c|c|c|c|}
\hline & Säilörehuseos ${ }^{1)}$ & Ohrakaura & Rypsipuriste & Soijapuriste \\
\hline Arginiini & 4.55 & 7.18 & 6.02 & 7.80 \\
\hline Histidiini & 2.04 & 2.58 & 2.83 & 2.83 \\
\hline Isoleusiini & 4.12 & 3.93 & 4.36 & 4.84 \\
\hline Leusiini & 7.25 & 7.52 & 7.88 & 8.15 \\
\hline Lysiini & 4.80 & 4.09 & 4.71 & 6.05 \\
\hline Metioniini & 1.72 & 1.69 & 2.18 & 1.15 \\
\hline Fenyylialaniini & 4.69 & 5.48 & 4.09 & 6.01 \\
\hline Treoniini & 4.65 & 3.91 & 5.18 & 4.01 \\
\hline Valiini & 5.70 & 5.53 & 5.35 & 5.07 \\
\hline Alaniini & 6.13 & 4.42 & 4.33 & 4.37 \\
\hline Asparagiinihappo & 10.08 & 7.85 & 8.87 & 12.17 \\
\hline Kystiini & 0.62 & 3.17 & 2.16 & 1.21 \\
\hline Glutamiinihappo & 10.4 & 22.8 & 16.4 & 19.6 \\
\hline Glysiini & 4.90 & 4.55 & 4.94 & 4.24 \\
\hline Proliini & 4.66 & 8.29 & 5.76 & 5.59 \\
\hline Seriini & 4.73 & 4.92 & 4.20 & 5.05 \\
\hline Tyrosiini & 3.24 & 3.77 & 3.35 & 4.23 \\
\hline Haaraketjuiset $^{2}{ }^{2}$ & 17.1 & 17.0 & 17.6 & 18.1 \\
\hline Välttämättömät ${ }^{3)}$ & 39.5 & 41.9 & 42.6 & 45.9 \\
\hline Ei-välttämättömät ${ }^{4)}$ & 44.8 & 59.8 & 50.0 & 56.4 \\
\hline Yhteensä $^{5)}$ (g/kg KA) & 133 & 130 & 344 & 491 \\
\hline
\end{tabular}

Taulukko 3. Valkuaislähteen (rypsi- tai soijapuriste) ja valkuaisrehun määrän vaikutus lypsylehmien syöntiin, ravintoaineiden saantiin ja sulavuuteen, kun säilörehu sisälsi puolet puna-apilaa.

\begin{tabular}{|c|c|c|c|c|c|c|c|c|c|c|}
\hline \multirow[b]{2}{*}{ Valkuaistaso } & \multirow{2}{*}{$\begin{array}{c}\text { Kontrolli } \\
0\end{array}$} & \multicolumn{2}{|c|}{ Rypsipuriste } & \multicolumn{2}{|c|}{ Soijapuriste } & \multirow{2}{*}{ SEM } & \multicolumn{4}{|c|}{ Tilastollinen merkitsevyys ${ }^{1)}$} \\
\hline & & 1 & 2 & 1 & 2 & & RvsS & Lin & Quad & $1 * \mathrm{~L}$ \\
\hline \multicolumn{11}{|c|}{ Rehujen syönti (kg kuiva-ainetta/pv) } \\
\hline Yhteensä & 19.6 & 21.4 & 21.7 & 20.3 & 20.7 & 0.45 & $*$ & $*$ & & \\
\hline Säilörehu & 12.7 & 13.3 & 13.6 & 12.3 & 13.0 & 0.38 & o & & & \\
\hline Vilja+valkuaisrehu & 6.89 & 7.96 & 7.42 & 7.80 & 7.24 & --- & & & & \\
\hline Valkuaisrehu & 0 & 1.78 & 3.34 & 1.34 & 2.51 & --- & & & & \\
\hline \multicolumn{11}{|c|}{ Ravintoaineiden saanti (kg/pv) } \\
\hline Orgaaninen aine & 18.4 & 20.1 & 20.2 & 19.0 & 19.3 & 0.43 & o & $*$ & & \\
\hline Raakavalkuainen & 2.89 & 3.62 & 4.15 & 3.47 & 4.07 & 0.064 & & $* * *$ & & \\
\hline Solunseinäkuitu & 8.85 & 9.60 & 9.75 & 8.89 & 9.02 & 0.192 & $* *$ & o & & $*$ \\
\hline ME (MJ) & 221.5 & 242.6 & 244.9 & 232.3 & 239.1 & 5.44 & & $*$ & & \\
\hline Rehuyksiköt (RY) & 18.9 & 20.7 & 20.9 & 19.9 & 20.4 & 0.47 & & $*$ & & \\
\hline OIV $(g)$ & 1766 & 2062 & 2210 & 1921 & 2045 & 42.5 & $* *$ & $* * *$ & & $*$ \\
\hline $\operatorname{PVT}(\mathrm{g})$ & -35 & 248 & 575 & 322 & 740 & 19.5 & $* * *$ & $* * *$ & & $* * *$ \\
\hline Fosfori (g) & 65.3 & 85.0 & 98.3 & 71.3 & 75.1 & 1.74 & $* * *$ & $* * *$ & & $* * *$ \\
\hline Kalsium (g) & 96.2 & 115.1 & 131.1 & 96.9 & 104.2 & 2.54 & $* * *$ & $* * *$ & & $* * *$ \\
\hline Magnesium (g) & 37.1 & 46.5 & 53.5 & 40.1 & 43.7 & 0.79 & $* * *$ & $* * *$ & & $* * *$ \\
\hline \multicolumn{11}{|l|}{ Sulavuus (g/kg) } \\
\hline Orgaaninen aine & 710 & 708 & 712 & 727 & 733 & 4.6 & $* *$ & o & & $*$ \\
\hline Raakavalkuainen & 618 & 642 & 672 & 663 & 704 & 7.6 & $* *$ & $* * *$ & & $*$ \\
\hline Solunseinäkuitu & 627 & 627 & 645 & 646 & 669 & 8.7 & $*$ & $*$ & & o \\
\hline Fosfori & 407 & 391 & 379 & 407 & 427 & 20.8 & & & & \\
\hline Kalsium & 335 & 342 & 324 & 339 & 359 & 21.7 & & & & \\
\hline Magnesium & 237 & 194 & 200 & 236 & 221 & 21.0 & & & & \\
\hline $\mathrm{N}$ satakertaan, $\mathrm{g} / \mathrm{d}$ & 549 & 625 & 662 & 617 & 631 & 17.6 & & $* *$ & & \\
\hline
\end{tabular}


miseen rypsipuristeen käyttömäärillä 1 ja 2 olivat 0.110 ja $0.064 \mathrm{~kg}$, kun vastaavat luvut soijapuristeruokinnoilla olivat 0.038 ja $0.025 \mathrm{~kg}$. OIV:n hyväksikäytössä rypsi- ja soijapuristeen välillä ei kuitenkaan ollut merkitsevää eroa (Taulukko 5), mikä tukee vuonna 2002 tehtyä soijavalkuaisen OIVarvojen pienentämistä (MTT 2004).

Kun perusrehuna käytettiin puolet apilaa sisältävää säilörehua ja valkuaisrehutäydennystä, lehmien makrokivennäisten tarve tyydyttyi ilman erillistä kivennäistäydennystä. Fosforin, kalsiumin ja magnesiumin näennäiset kokonaissulavuudet olivat keskimäärin 402, 340 ja $281 \mathrm{~g} / \mathrm{kg}$ eivätkä koeruokinnat vaikuttaneet niihin merkitsevästi (Taulukko 3). Lucasin yhtälöllä lasketut lisäfosforin ja kalsiumin todelliset sulavuudet olivat rypsipuristeessa 302 ja 270 mutta soijapuristeessa 620 ja 751 $\mathrm{g} / \mathrm{kg}$. Soijapuristeen kivennäisten sulavuudet olivat siis selvästi rypsipuristetta korkeammat.

Ravinteiden hyväksikäyttö maataloudessa on noussut yhä tärkeämmäksi asiaksi. Tässä kokeessa typen hyväksikäyttö maidontuotannossa (g maidon typpeä / kg rehujen typpeä) oli keskimäärin $283 \mathrm{~g} / \mathrm{kg}$. Hyväksikäyttö huononi merkitsevästi, kun rehuannokseen lisättiin valkuaisrehuja ja soijan valkuaisen hyväksikäyttö jäi huonommaksi kuin rypsin (Taulukko 5). Pötsinesteen ja plasman ammoniakkipitoisuuksien sekä maidon ureapitoisuuden nousu valkuaislisän myötä ja soijapuristetta saaneiden lehmien suuremmat arvot rypsipuristetta syöneisiin verrattuna kuvaavat samaa ilmiötä eli rehuvalkuaisen hyväksikäytön heikentymistä.

Taulukko 4. Valkuaislähteen (rypsi- tai soijapuriste) ja valkuaisrehun määrän vaikutus lypsylehmien plasman ravintoaineiden (mmol/l) ja aminohappojen pitoisuuksiin.

\begin{tabular}{|c|c|c|c|c|c|c|c|c|c|c|c|}
\hline \multirow[b]{2}{*}{ Valkuaistaso } & \multirow{2}{*}{$\begin{array}{l}\text { Kont- } \\
\text { rolli }\end{array}$} & \multicolumn{2}{|c|}{ Rypsipuriste } & \multicolumn{2}{|c|}{ Soijapuriste } & \multirow{2}{*}{ SEM } & \multicolumn{5}{|c|}{ Tilastollinen merkitsevyys ${ }^{1)}$} \\
\hline & & 1 & 2 & 1 & 2 & & RvsS & $\mathrm{L}$ & $\mathrm{Q}$ & $1 * \mathrm{~L}$ & $1 * \mathrm{Q}$ \\
\hline Glukoosi & 3.32 & 3.45 & 3.47 & 3.30 & 3.34 & 0.092 & & & & & \\
\hline NEFA $^{2)}$ & 0.296 & 0.167 & 0.158 & 0.207 & 0.195 & 0.0398 & & $*$ & & & \\
\hline BHBA $^{3)}$ & 1.22 & 1.14 & 0.84 & 0.98 & 1.31 & 0.152 & & & & o & \\
\hline Urea & 3.74 & 4.29 & 4.80 & 4.55 & 6.44 & 0.303 & $*$ & $* * *$ & & $* *$ & \\
\hline Etikkahappo & 1.82 & 1.78 & 1.66 & 1.59 & 1.84 & 0.150 & & & & & \\
\hline Insuliini $(\mu \mathrm{mol} / \mathrm{l})$ & 3.27 & 4.40 & 3.71 & 3.30 & 5.34 & 0.719 & & & & & \\
\hline \multicolumn{12}{|l|}{ Aminohapot $(\mu \mathrm{mol} / \mathrm{l})$} \\
\hline Arginiini & 82.4 & 82.8 & 94.2 & 98.6 & 83.0 & 8.19 & & & & & \\
\hline Histidiini & 34.9 & 44.2 & 46.9 & 45.5 & 45.4 & 2.89 & & $*$ & & & \\
\hline Isoleusiini & 161.0 & 181.1 & 183.3 & 181.9 & 186.8 & 19.41 & & & & & \\
\hline Leusiini & 136.0 & 176.9 & 205.9 & 175.8 & 193.2 & 17.61 & & $*$ & & & \\
\hline Lysiini & 83.8 & 90.5 & 91.0 & 101.2 & 82.0 & 8.50 & & & & & \\
\hline Metioniini & 15.3 & 15.9 & 18.8 & 17.3 & 12.5 & 1.16 & $\mathrm{o}$ & & & $* *$ & $*$ \\
\hline Fenyylialaniini & 43.8 & 49.5 & 51.9 & 56.3 & 51.2 & 2.67 & & $*$ & o & & \\
\hline Treoniini & 94.7 & 109.2 & 122.7 & 109.2 & 92.0 & 6.80 & o & & & $*$ & \\
\hline Tryptofaani & 21.4 & 19.7 & 20.5 & 19.9 & 18.9 & 1.00 & & & & & \\
\hline Valiini & 301 & 365 & 411 & 351 & 399 & 33.9 & & $*$ & & & \\
\hline Alaniini & 214.8 & 215.0 & 227.6 & 237.2 & 172.3 & 9.16 & & & o & $* *$ & $* *$ \\
\hline Asparagiini & 50.1 & 55.5 & 53.2 & 57.3 & 48.2 & 5.77 & & & & & \\
\hline Aspartaatti & 6.6 & 7.6 & 7.1 & 8.6 & 7.0 & 0.42 & & & $*$ & & \\
\hline Sitrulliini & 82.8 & 75.8 & 77.8 & 86.2 & 89.3 & 5.30 & o & & & & \\
\hline Kystiini & 18.5 & 19.7 & 22.4 & 18.2 & 18.0 & 1.56 & o & & & o & \\
\hline Glutamiini & 206.3 & 194.7 & 203.5 & 206.7 & 185.5 & 9.10 & & & & & \\
\hline Glutamaatti & 44.1 & 42.0 & 38.9 & 41.6 & 37.9 & 2.21 & & o & & & \\
\hline Glysiini & 373.0 & 352.9 & 338.6 & 352.8 & 281.0 & 14.99 & $\mathrm{o}$ & $* *$ & & $*$ & \\
\hline 3-Met-histidiini & 6.34 & 7.17 & 7.08 & 6.77 & 7.59 & 0.782 & & & & & \\
\hline Ornitiini & 40.5 & 45.4 & 54.2 & 48.6 & 49.1 & 4.57 & & o & & & \\
\hline Proliini & 78.9 & 83.2 & 98.1 & 93.1 & 96.9 & 7.49 & & o & & & \\
\hline Seriini & 81.0 & 88.8 & 99.2 & 98.5 & 82.2 & 5.20 & & & & o & o \\
\hline Tauriini & 31.1 & 32.5 & 42.4 & 47.1 & 46.8 & 5.24 & & $\mathrm{o}$ & & & \\
\hline Tyrosiini & 38.8 & 47.5 & 49.9 & 50.5 & 45.1 & 4.00 & & & & & \\
\hline Haaraketjuiset $^{4)}$ & 598 & 723 & 801 & 709 & 778 & 69.9 & & o & & & \\
\hline Välttämättömät & 974 & 1135 & 1247 & 1157 & 1163 & 93.5 & & o & & & \\
\hline Ei-välttämättömät ${ }^{6)}$ & 1112 & 1107 & 1139 & 1165 & 974 & 34.4 & & & & $* *$ & $*$ \\
\hline Yhteensä7) $^{7}$ & 2087 & 2242 & 2385 & 2321 & 2137 & 124.6 & & & & & \\
\hline
\end{tabular}

${ }^{1)}$ Ks. Taulukko $3{ }^{2)}$ Vapaat rasvahapot ${ }^{3)} \beta$-hydroksivoihappo ${ }^{4-7)}$ Ks. Taulukko 2 


\section{Johtopäätökset}

Tässä kokeessa selvitettiin rypsi- ja soijapuristeen maidontuotantopotentiaalia luomutuotantoon soveltuvassa ruokintamallissa, jossa säilörehu sisälsi puolet puna-apilaa. Lypsylehmien maidontuotantovasteet olivat samaa luokkaa kuin aikaisemmissa kotimaisissa kokeissa, jotka oli suoritettu nurmiheinäkasveista tehtyyn säilörehuun perustuvia ruokintoja käyttäen. Rypsipuriste osoittautui myös tässä kokeessa soijapuristetta paremmaksi valkuaistäydennykseksi, kun maitotuotosvaste laskettiin valkuaisrehukiloja tai rehun raakavalkuaista kohti. Kokeessa käytettiin kohtuullisen runsaita valkuaisrehuannoksia. Maitotuotosvasteet olivat suurempia ensimmäisen kuin toisen lisäysmäärän jälkeen erityisesti rypsipuristetta käytettäessä, vaikka toisen asteen vaikutus ei tilastollisessa analyysissä tullut merkitseväksi. Typen hyväksikäyttö maidontuotannossa huononi valkuaisrehuannosta lisättäessä ja oli soijapuristetta käytettäessä huonompi kuin rypsipuristeella. Ravinteiden hyväksikäyttö maidontuotannossa ei kuitenkaan vaikuta suoraan karjatilan taloudelliseen tulokseen, joten valkuaisrehun taloudellinen käyttömäärä riippuu pääasiassa maidon ja rehujen keskinäisistä hinnoista.

\section{Kirjallisuus}

Kokkonen, T. 2005. Energy and protein nutrition of dairy cows during the dry period and early lactation: Production performance and adaptation from pregnancy to lactation. Helsingin yliopiston kotieläintieteen laitoksen julkaisuja 77. $56 \mathrm{~s}+4$ liitettä. Saatavissa: http://ethesis.helsinki.fi/julkaisut/maa/kotie/vk/kokkonen/

MTT 2004 Rehutaulukot ja ruokintasuositukset [verkkojulkaisu]. Jokioinen: Maa- ja elintarviketalouden tutkimuskeskus. Julkaistu 30.6.2004. Saatavissa: http://www.agronet.fi/rehutaulukot/

Rinne, M. , Jaakkola, S., Varvikko, T. \& Huhtanen, P. 1999. Effects of the type and amount of rapeseed feed on milk production. Acta Agriculturæ Scandinavica, Section A Animal Science, 49: 137-148.

Vanhatalo, A., Huhtanen, P., Toivonen, V. \& Varvikko, T. 1999. Response of dairy cows fed grass silage diets to abomasal infusions of histidine alone or in combinations with methionine and lysine. Journal of Dairy Science 82: 2674-2685.

Vanhatalo, A., Huhtanen, P., Korhonen, M. \& Varvikko, T. 2002. Aminohappotäydennyksen vaikutus lypsylehmien maidontuotantoon ja ravintoaineiden metaboliaan säilörehupohjaisella ruokinnalla. Maataloustieteen Päivät 2002, Kotieläintiede. toim. Marketta Rinne. MKL:n julkaisuja nro 977. pp. 119-122.

Vanhatalo, A., Shingfield, K., Pahkala, E., Salo-Väänänen, P., Korhonen, H., Piironen, V. \& Huhtanen, P. 2004. Rypsi ja soija lypsylehmien valkuaislähteenä. Julkaisussa: Maataloustieteen Päivät 2004 [verkkojulkaisu]. Suomen Maataloustieteellisen Seuran tiedote no 19. Toim. A. Hopponen ja M. Rinne. Julk. 5.1.2004. Saatavilla Internetissä: http://www.agronet.fi/maataloustieteellinenseura/julkaisut/esi04/ma03.pdf. ISBN 951-9041-47-8.

Taulukko 5. Valkuaislähteen (rypsi- tai soijapuriste) ja valkuaisrehun määrän vaikutus lypsylehmien maidontuotantoon, kun säilörehu sisälsi puolet puna-apilaa.

\begin{tabular}{|c|c|c|c|c|c|c|c|c|c|c|}
\hline \multirow[b]{2}{*}{ Valkuaistaso } & \multirow{2}{*}{$\begin{array}{c}\text { Kontrolli } \\
0\end{array}$} & \multicolumn{2}{|c|}{ Rypsipuriste } & \multicolumn{2}{|c|}{ Soijapuriste } & \multirow{2}{*}{ SEM } & \multicolumn{4}{|c|}{ Tilastollinen merkitsevyys ${ }^{1)}$} \\
\hline & & 1 & 2 & 1 & 2 & & RvsS & Lin & Quad & $1 * \mathrm{~L}$ \\
\hline \multicolumn{11}{|c|}{ Maidontuotanto päivässä } \\
\hline Maito (kg) & 32.7 & 35.3 & 35.8 & 33.7 & 34.1 & 0.91 & & o & & $*$ \\
\hline EKM (kg) & 31.1 & 34.0 & 34.5 & 32.2 & 32.4 & 0.57 & $* *$ & $*$ & & $*$ \\
\hline Rasva (g) & 1220 & 1321 & 1357 & 1272 & 1255 & 37.0 & $\mathrm{o}$ & o & & \\
\hline Valkuainen $(\mathrm{g})$ & 968 & 1087 & 1092 & 991 & 1033 & 26.8 & $*$ & $*$ & & \\
\hline Laktoosi (g) & 1620 & 1759 & 1763 & 1673 & 1687 & 41.0 & o & o & & \\
\hline \multicolumn{11}{|c|}{ Maidon koostumus (g/kg) } \\
\hline Rasva & 37.6 & 37.7 & 38.2 & 38.0 & 37.0 & 1.59 & & & & \\
\hline Valkuainen & 29.8 & 30.9 & 30.7 & 29.5 & 30.4 & 0.48 & & & & \\
\hline Laktoosi & 49.5 & 49.8 & 49.3 & 49.6 & 49.5 & 0.31 & & & & \\
\hline Urea $(\mathrm{mg} / 100 \mathrm{ml})$ & 18.1 & 25.8 & 29.9 & 26.1 & 34.0 & 1.91 & & $* * *$ & & \\
\hline OIV:n hyv.käyttö2) & 0.776 & 0.711 & 0.656 & 0.705 & 0.682 & 0.0172 & & $* * *$ & & \\
\hline Typen hyv.käyttö2) & 332 & 294 & 258 & 280 & 249 & 5.9 & o & $* * *$ & & \\
\hline
\end{tabular}

${ }^{1)}$ Ks. Taulukko 3

${ }^{2)}$ OIV:n hyväksikäyttö = maidon valkuainen $(\mathrm{g}) /(\mathrm{OIV}: \mathrm{n}$ saanti - OIV ylläpitoon $(\mathrm{g}))$

${ }^{3}$ Typen hyväksikäyttö = maidon typpi $(\mathrm{g}) /$ syötyjen rehujen typpi $(\mathrm{kg})$ 